\title{
STRATEGI PROMOSI PERSONAL SELLING DALAM MENCAPAI TARGET PRODUK KREDIT KOMERSIAL PADA PT BANK PEMBANGUNAN DAERAH JAWA BARAT DAN BANTEN, TBK CABANG BANJARMASIN
}

\author{
Novi Shintia, Ronny Mantala, Muhammad Irfan \\ Politeknik Negeri Banjarmasin \\ E-mail: Novi_shintia@yahoo.co.id, rmantala@gmail.com, $\underline{\text { irfan.muhammad178@gmail.com }}$
}

\begin{abstract}
PT Bank Pembangunan Daerah Jawa Barat dan Banten, Tbk Banjarmasin Branch is a governmentowned commercial bank in the area of West Java and Banten. The purpose of this study is 1) To find out how the personal-selling strategy carried out by the Regional Development Bank of West Java and Banten, Tbk Banjarmasin Branch. 2) To find out the right strategy in achieving the target of Commercial Credit products at PT Regional Development Banks of West Java and Banten, Tbk Banjarmasin Branch. This study uses descriptive approach, using primary data and secondary data, involving dependent and independent variable, data collection techniques employed the observation $\&$ interview and data analysis techniques used are qualitative analysis. The results of the study show 1) the implementation of personal selling strategies that have been carried out there are several ways, namely referral, territorial management and internal data mining. However, from some of its implementation, it has not been able to develop properly and the implementation is less than optimal and appropriate. Problem solving in this study by using appropriate personal selling strategies, namely 1) prospecting, 2) communicating, 3) selling, 4) information gathering, 5) servicing, 6) allocating. Then steps can be used such as: prospects and qualifications, preapproach, presentation and demonstration, overcoming objections, closing, and follow-up and maintenance.
\end{abstract}

Keywords: Information Systems, Software Development Life Cycle, SDLC, Banjarmasin City Tourism

\begin{abstract}
Abstrak
PT Bank Pembangunan Daerah Jawa Barat dan Banten, Tbk Cabang Banjarmasin adalah bank umum milik pemerintah di daerah Jawa Barat dan Banten. Tujuan penelitian ini 1) Untuk mengetahui bagaimana strategi promosi personal selling yang dilakukan oleh PT Bank Pembangunan Daerah Jawa Barat dan Banten, Tbk Cabang Banjarmasin. 2) Untuk mengetahui strategi yang tepat dalam mencapai target produk Kredit Komersial pada PT Bank Pembangunan Daerah Jawa Barat dan Banten, Tbk Cabang Banjarmasin. Penelitian ini menggunakan metode desktriftif, sumber data yaitu data primer dan data sekunder, variabel penelitian adalah variabel bebas dan variabel terikat, Teknik pengumpulan data adalah observasi dan wawancara dan teknik analisis data yang digunakan adalah analisis kualitatif. Hasil penelitian Menunjukan 1) pelaksanaan strategi personal selling yang telah dilakukan ada beberapa cara yaitu referral, territorial management dan internal data mining. Namun dari beberapa pelaksanaanya masih belum dapat berkembang dengan baik dan pelaksanaan yang kurang maksimal dan tepat. Pemecahan masalah dalam penelitian ini dengan menggunakan strategi personal selling yang tepat yaitu 1) prospecting, 2) communicating, 3) selling, 4) information gathering, 5) servicing, 6) allocating. Kemudian Langkah-langkah yang bisa digunakan seperti: prospek dan mengkualifikasi, prapendekatan, persentasi dan demonstrasi, mengatasi keberatan, penutupan, serta tindak lanjut dan pemeliharaan.
\end{abstract}

Kata kunci: Strategi, Personal Selling, Kredit Komersial 


\section{PENDAHULUAN}

Pada saat ini dunia perbankan di Indonesia memasuki masa persaingan yang sangat kompetitif. Hal ini disebabkan banyaknya bank serta lembaga keuangan lainnya yang beroperasi di Indonesia. Peranan bank juga sebagai lembaga keuangan tidak pernah lepas dari masalah kredit. Bahkan kegiatan bank sebagai lembaga keuangan, pemberian kredit merupakan kegiatan utamanya.

PT Bank Pembangunan Daerah Jawa Barat dan Banten, Tbk Cabang Banjarmasin yang dikenal dengan nama Bank bjb Cabang Banjarmasin adalah bank umum milik pemerintah di daerah Jawa Barat dan Banten yang usahanya di bidang jasa yaitu menghimpun dana, menyalurkan dana, dan memberikan jasa lainnya. Kegiatan menyalurkan dana, berupa pemberian pinjaman kepada masyarakat seperti dalam bentuk produk kredit. Salah satu produk kredit yang ada di Bank bjb Kantor Cabang Banjamasin adalah Kredit Komersial. Kredit Komersial yang ada di PT Bank Pembangunan Daerah Jawa Barat dan Banten, Tbk Cabang Banjarmasin 0020 terbagi menjadi 3 produk yaitu : Kredit Modal Kerja (KMK), Kredit Modal Kerja Kontruksi (KMKK) dan Kredit Investasi.

Berdasarkan pengamatan peneliti, PT Bank Pembangunan Daerah Jawa Barat dan Banten, Tbk Cabang Banjarmasin mengalami target realisasi penyaluran dana kredit yang seluruhnya belum tercapai sehingga dalam kurun waktu beberapa tahun terakhir mengalami tidak tercapainya target penyaluran dana produk Kredit Komersial.

Padahal dalam pencapaian target diatas, pencapaian target itu sangat penting karena diharapkan sebagai keberhasilan perusahaan tersebut. Dengan demikian perlu kiranya dari kegiatan pelaksanaan promosi melalui personal selling yang dilakukan perlu diperbaharui serta ditingkatkan agar dapat mendongkrak dan perluasan pasar sasaran dalam pencapaian penyaluran dana produk Kredit Komersial kepada nasabah yang berpotensial serta mampu membuat mempertahankan eksistensi usahanya secara berkelanjutan.

Oleh karena itu, berdasarkan latar belakang masalah diatas, peneliti tertarik ingin mengangkatnya dengan judul "Strategi Promosi Personal Selling Dalam Mencapai Target Produk Kredit Komersial pada PT Bank Pembangunan Daerah Jawa Barat dan Banten, Tbk Cabang Banjarmasin”.

\section{TINJAUAN PUSTAKA}

\section{Strategi}

Kata strategi dari bahasa yunani "Strategia" yang diartikan sebagai "the art of the general" atau seni seorang panglima yang biasanya digunakan dalam peperangan.

Menurut Kotler (2008:25) strategi adalah proses manajerial untuk mengembangkan dan menjaga keserasian antara tujuan perusahaan, sumber daya perusahaan, dan peluang pasar yang terus berubah, dengan tujuan untuk membentuk dan menyesuaikan usaha perusahaan dan produk yang dihasilkan sehingga bisa mencapai keuntungan dan tingkat pertumbuhan yang menguntungkan.

\section{Pemasaran}

Menurut Kotler dan Keller (2012:12) "Marketing is the activity, set of institutions, and processes for creating, communicating, delivering, and exchanging offerings that have value for customers, clients, partners, and society at large". Artinya pemasaran adalah kegiatan, serangkaian institusi, dan proses untuk menciptakan, berkomunikasi, memberikan, dan bertukar penawaran yang memiliki nilai pelanggan, klien, mitra, dan masyarakat luas. 
Menurut Kotler dan Armstrong (2012:58) menyatakan bahwa bauran pemasaran adalah "The set of controllable tactical marketing tools product, price, place, and promotion that firm blends to produce the response it wants in the target market". Artinya Seperangkat alat pemasaran taktis yang dapat dikontrol seperti: produk, harga, tempat, dan promosi yang dipadukan perusahaan untuk menghasilkan respons yang diinginkan dalam target pasar.

Adapun perangkat atau elemen dari bauran pemasaran menurut Kotler dan Keller (2012:25) adalah product, price, place, dan promotion. Berikut ini penjelasan tentang elemen- elemen bauran pemasaran:

\section{Product (produk)}

Product is anything that can be offered to a market for attention, acquisition, use, or consumption that might satisfy a want or need". Dari pendapat Kotler dan Keller tersebut dapat dikatakan produk adalah sesuatu yang dapat ditawarkan perusahaan ke pasar untuk mendapatkan perhatian, perolehan, penggunaan, atau konsumsi yang mungkin memuaskan keinginan atau kebutuhan.

\section{Price (harga)}

"Price is the amount of money changed for a product or service“. Dari pendapat Kotler dan Keller tersebut dapat dikatakan harga adalah jumlah yang harus disiapkan oleh pelanggan yang ingin mendapatkan barang atau jasa.

\section{Place (tempat)}

"Place is a set of independent organizations that help make a product or service available for use consumption by the consumer or business user". Dari pendapat Kotler dan Keller tersebut, maka dapat dikatakan lokasi sebagai kumpulan dari organisasi-organisasi yang independen, yang membuat suatu barang atau jasa menjadi tersedia sehingga pelanggan dapat menggunakan atau mengkonsumsi barang atau jasa tersebut.

\section{Promotion (Promosi)}

"Promotion is the specific blend of advertising, sales promotion, public relation, personal selling, and direct marketing tools that the company uses to persuasively communicate customer value and build customer relationship". Artinya promosi adalah perpaduan spesifik dari iklan, promosi penjualan, hubungan masyarakat, penjualan pribadi, dan alat pemasaran langsung yang digunakan perusahaan untuk secara persuasif mengomunikasikan nilai pelanggan dan membangun hubungan kepada pelanggan.

\section{Promosi}

Salah satu yang menunjang keberhasilan penjualan adalah promosi, promosi digunakan perusahaan untuk memperkenalkan produk kepada masyarakat luas agar kesadaran terhadap suatu produk perusahaan lebih meningkat serta untuk menginformasikan manfaat dari suatu produk. Adapun pengertian promosi menurut para ahli:

Menurut Kotler dan Keller (2012:204) komunikasi pemasaran (promosi) adalah sarana yang digunakan oleh perusahaan dalam upaya untuk menginformasikan, membujuk, dan mengingatkan konsumen langsung atau tidak langsung tentang produk dan merek yang mereka jual.

\section{Bauran Promosi}

Bauran promosi merupakan alat komunikasi yang terdiri dari kombinasi alat alat promosi yang digunakan oleh perusahaan. Pada umumnya alat-alat promosi tersebut memiliki hubungan yang erat, sehingga diantaranya tidak dapat dipisahkan, karena bersifat saling mendukung dan melengkapi.

Menurut Kotler dan Amstrong (2012:363) bauran promosi adalah perpaduan spesifik iklan, promosi penjualan, hubungan masyarakat, penjualan personal, dan sarana pemasaran langsung yang digunakan perusahaan untuk mengkomunikasikan nilai pelanggan secara persuasive dan membangun 
hubungan pelanggan secara umum bentukbentuk memiliki fungsi yang sama, tetapi bentuk-bentuk tersebut dapat dibedakan berdasarkan tugas-tugas khususnya. Beberapa tugas khusus itu disebut bauran promosi adalah penjualan perorangan, periklanan, promosi penjualan, hubungan masyarakat dan penjualan langsung".

\section{Personal Selling}

Kegiatan persona selling merupakan bagian dari kegiatan promosi yaitu cara untuk memperkenalkan dan menarik minat konsumen terhadap produk yang di tawarkan secara tatap muka. Promosi ini merupakan salah satu variabel di dalam marketing mix yang sangat penting untuk dilaksanakan oleh perusahaan dalam menawarkan produknya. Dalam hal ini berikut ada beberapa definisi menurut para ahli pengertian personal selling.

Menurut Kotler dan Armstrong (2012:416) "Personal Selling is the most effective tool at certain stages of the buying proceses, particulary in building up buyer prefrences, convictions, and actions". Artinya personal selling adalah alat yang paling efektif pada tahap tertentu dari proses pembelian, terutama dalam membangun preferensi, keyakinan, dan tindakan pembeli.

\section{Bentuk-bentuk Personal Selling}

Menurut Mc Carthy (2008:396) bentuk-bentuk personal selling adalah sebagai berikut:

\section{a. Responsive selling}

Responsive selling merupakan bentuk personal selling dimana penjual bertugas untuk memenuhi permintaan konsumen. Dimana pada tipe ini sales people mengadakan perjalanan dan menjumpai banyak pengecer.

\section{b. Trade selling}

Trade selling merupakan bentuk personal selling dimana penjual bertindak sebagai order taker (menerima pesan) tetapi lebih fokus pada pelayanan.

\section{c. Missionary selling}

Missionary selling merupakan bentuk personal selling dimana penjual memiliki tugas untuk mempromosikan produk baru, terkadang juga melakukan order taker.

d. Technical selling

Technical selling merupakan bentuk personal selling dimana penjual menyelesaikan masalah konsumen dengan keahlian dan pengalaman yang telah dimilikinya.

\section{e. Creative selling}

Creative selling merupakan bentuk personal selling yang biasanya berhubungan dengan produk, mengenai masalah yang dianggap serius dan memberikan solusi yang terbaik.

\section{Langkah-langkah Personal Selling}

Kotler dan Keller (2012:272-273) menjelaskan tedapat enam langkah Personal Selling yaitu:

1. Mencari calon pelanggan (prospek) dan mengkualifikasinya

Langkah pertama dalam penjualan adalah mengidentifikasi pelanggan dan mengkualifikasi. Semakin banyak perusahaan yang bertanggung jawab untuk mencari dan mengkualifikasikan petunjuk sehingga wiraniaga dapat menggunakan waktu mereka yang tidak banyak untuk melakukan apa yang dapat mereka lakukan dengan baik. Perusahaan mengkualifikasikan dengan menghubungi calon pelanggan lewat surat atau telepon untuk menilai tingkat minat dan kasisitas uang mereka.

\section{Prapendekatan}

Wiraniaga harus belajar sebanyak mungkin calon pembelinya. Wiraniaga harus menetapkan tujuan kunjungan, mengkualifikasi calon pelanggan, mengumpulkan informasi, melakukan penjualan segera. Tugas lain adalah memilih pendekatan kontak terbaik, apakah kunjungan pribadi, telepon atau surat. Pada akhirnya, wiraniaga harus merencanakan 
keseluruhan strategi penjualan untuk pelanggan.

\section{Presentasi dan demonstrasi}

Wiraniaga menyampaikan "kisah" produk kepada pembeli menggunakan pendekatan fitur, keunggulan (advantage), manfaat (benefit), dan nilai (value) (FABV). Fitur menggambarkan karakteristik fisik penawaran pasar, seperti kecepatan pemrosesan chip atau kapasitas memori. Keunggulan menjelaskan mengapa fitur itu memberikan keuntungan kepada pelanggan. Manfaat menggambarkan, manfaat ekonomi, teknis layanan dan sosial yang dihantarkan oleh penawaran.Nilai menggambarkan niliai penawaran.Wiraniaga sering menghabiskan terlalu banyak watku dalam fitur produk dan tidak cukup waktu menekankan sisi manfaat dan nilai.

\section{Mengatasi keberatan}

Pelanggan biasanya mengajukan keberatan. Resistensi psikologis meliputi resistensi terhadap interferensi, preferensi terhadap sumber pasokan atau merek yang sekarang digunakan, apatis, tidak bersedia melupakan sesuatu, hubungan tidak menyenangkan diciptakan oleh wiraniaga.Untuk menangani keberatan ini wiraniaga mempertahankan pendekatan positif, meminta pembeli menglarifikasi keberatan, mengajukan pertanyaan dengan cara di mana pembeli menjawab keberatannya sendiri, menyangkal keakuratan hal yang menjadi keberatan tersebut, atau mengubah menjadi alasan untuk membeli.

\section{Penutupan}

Tanda penutupan dari pembeli meliputi tindakan fisik, pernyataan atau komentar dan pertanyaan. Wiraniaga dapat menanyakan pesan, merekapitulasi poin-poin yang disepakati, menawarkan untuk membantu menulis pesanan, bertanya apakah menginginkan produk $\mathrm{A}$ atau produk $\mathrm{B}$, membuat pembeli mengambil pilihan kecil seperti warna atau ukuran, atau menunjukan kerugian apa yang dapat dialami pembeli jika tidak melakukan pemesanan sekarang.
Wiraniaga dapat menawarkan insentif khusus untuk menutup, seperti harga khusus, kuantitas ekstra, atau cinderamata.

\section{Tindak lanjut dan pemeliharaan}

Tindak lanjut dan pemeliharaan diperlukan untuk memastikan kepuasan pelanggan dan terluangnya kerja sama. Segera setelah menutup penjualan, wiraniaga harus menyatukan semua data yang diperlukan tentang waktu pengiriman, syarat pembelian, dan masalah penting bagi pelanggan. Wiraniaga harus menjadwalkan kunjungan tindakan lanjut setelah pengiriman untuk memastikan pemasangan, instruksi, dan layanan yang tepat dan mendekteksi semua masalah, memastikan minat wiraniaga kepada pembeli, dan mengurangi disonansi kognitif. Wiraniaga harus mengembangkan rencana pemeliharan dan pertumbuhan bagi pelanggan.

\section{Strategi Personal Selling Dalam Perbankan}

Dalam perbankan penjualan pribadi secara umum dilakukan oleh seluruh pegawai bank, mulai dari cleaning service, satpam sampai pejabat bank. Secara khusus penjualan pribadi dilakukan oleh costumer service atau service assistensi. Para petugas mempunyai kesempatan untuk berkomunikasi langsung dengan konsumen sehingga lebih leluasa dalam menjelaskan manfaat produk bank yang sedang mereka promosikan. Kegiatan promosi ini penting peranannya untuk mempopulerkan produk bank yang lebih komplek sifatnya. dalam personal selling cara penyampaiaan pesan promosi juga dapat disesuaikan dengan selera masing-masing konsumen. Para petugas pemasaran juga merupakan ujung tombak perusahaan dalam menjalin relasi dengan pelanggan.

Menurut Saladin , tugas dari personal selling terbagi menjadi enam, yaitu:

1. Mencari calon pembeli (prospecting)

Personal selling setuju untuk mencari pelanggan bisnis baru yang kemudian 
dijadikan sebagai pelanggan bisnis potensial bagi perusahaannnya.

\section{Komunikasi (communicating)}

Personal selling memberikan informasi yang dibutuhkan oleh pelanggan bisnis tentang produk yang jelas dan tepat.

\section{Penjualan (selling)}

Personal selling harus tahu seni menjual, mendekati pelanggan bisnis sasaran, mempresentasikan produk, menjawab keberatan-keberatan, menutup penjualan.

\section{Mengumpulkan Informasi (information} gathering)

Personal selling melakukan riset pasar sehingga mendapatkan informasi tentang pelanggan bisnis dan keadaan pasar serta membuat laporan kunjungan baik yang akan dilakukan maupun yang telah dilakukan.

\section{Pelayanan (servicing)}

Personal selling melakukan pelayanan kepada pelanggan bisnis, mengkomunikasikan masalah pelanggan bisnis, memberikan bantuan teknis dan melakukan pengiriman.

6. Pengalokasian (allocation)

Personal selling setuju untuk memutuskan pelanggan bisnis mana yang akan lebih dulu memperoleh produk bila terjadi kekurangan produk pada produsen.

\section{Target}

Target mempunyai kesamaan dengan sasaran, yaitu penjabaran dari tujuan secara teratur, yang akan dicapai/di hasilkan secara nyata oleh suatu organisasi dalam jangka tahunan, semesteran, triwulanan, atau wulanan. Kemudian pengertian target dikutip dari Kamus Besar Bahasa Indonesia terbitan Departemen Pendidikan dan Kebudayaan dari Balai Pustaka (1991: 1011) target adalah sasaran (batas Ketentuan dan sebagainya) yang telah ditetapkan untuk dicapai.

\section{Sifat Target atau Sasaran}

Berikut ini adalah sejumlah sifat yang mendukung kriteria bagi target sasaran yaitu sebagai berikut:
1. Sesuai dengan manfaat dan misi organisasi

2. Realistis

3. Dapat diterima masyarakat organisasi

4. Luwes terhadap resiko

5. Memberikan motivasi

6. Dipahami oleh anggota

7. Keterkaitan antar sasaran

8. Terukur dalam pengertian waktu

9. Spesifik

Sedangkan Menurut UU No. 10 Tahun 1998 (UU Perbankan) mendefinisikan kredit sebagai penyediaan uang atau tagihan yang dapat dipersamakan dengan itu, berdasarkan persetujuan atau kesepakatan pinjam meminjam antara bank dengan pihak lain yang mewajibkan pihak peminjam untuk melunasi utangnya setelah jangka waktu tertentu dengan pemberian bunga.

\section{Kredit Komersial}

Kredit Komersial merupakan kredit yang oleh nasabahnya (perorangan atau badan usaha) dipergunakan untuk memperlancar kegiatan nasabah yang bidang usahanya adalah perdagangan (ditujukan untuk membiayai kebutuhan dunia usaha), baik dalam bentuk kredit revolving maupun kredit dalam bentuk nonrevolving. Sumber pembayarannya berasal dari usaha yang dibiayainya itu.

Adapun usaha atau produk Kredit Komersial yang terdapat pada PT Bank Pembangunan Daerah Jawa Barat dan Banten, Tbk Cabang Banjarmasin Terdiri dari:

\section{1. bjb Kredit Modal Kerja (KMK)}

Kredit Modal Kerja yaitu fasilitas kredit untuk membiayai aset lancar atau kegiatan operasional perusahaan sesuai dengan karakter bisnis debit.

1) Fitur Produk

a. Sifat kredit Revolving atau Non Revolving 
b. Faslitas kredit dapat diberikan dalam mata uang rupiah maupun valuta asing

c. Jangka waktu fasilitas kredit maksimum 5 (lima) tahun

d. Penarikan dapat dilakukan setiap saat sesuai kebutuhan usaha

e. Tingkat suku bunga bersaing

2) Persyaratan

a. Dokumen legalitas pemohon (KTP, Anggaran Dasar perusahaan)

b. Dokumen legalitas usaha (NPWP, SIUP, SITU, TDP)

\section{2. bjb Kredit Modal Kerja Konstruksi}

Kredit Modal Kerja Kontruksi yaitu Fasilitas kredit untuk membiayai kebutuhan modal kerja kontraktor yang memperoleh kontrak pengadaan barang/jasa dalam rangka pelaksanaan pekerjaan konstruksi, jasa konsultasi atau jasa lainnya.

1) Fitur Produk

a. Sifat

kredit Revolving atau Non Revolving

b. Fasilitas kredit dapat diberikan dalam mata uang rupiah maupun valuta asing

c. Jangka waktu sesuai dengan pelaksanaan proyek dalam Underlying Transaction

d. Tingkat suku bunga bersaing

2) Persyaratan

a. Dokumen legalitas pemohon (KTP, Anggaran Dasar perusahaan)

b. Dokumen legalitas usaha (NPWP, SIUP, SITU, TDP)

\section{3. bjb Kredit Investasi}

Kredit Investasi yaitu Fasilitas kredit yang diberikan untuk membiayai kebutuhan barang modal atau aset tetap dalam rangka rehabilitasi, modernisasi, ekspansi (perluasan), relokasi, project financing atau refinancing.

1) Fitur Produk

a. Sifat kredit Non Revolving

b. Jangka waktu fasilitas kredit maksimum 12 (dua belas) tahun c. Fasilitas kredit dapat diberikan dalam mata uang rupiah maupun valuta asing

d. Tingkat suku bunga bersaing

2) Persyaratan

a. Dokumen legalitas pemohon (KTP, Anggaran Dasar perusahaan)

b. Dokumen legalitas usaha (NPWP, SIUP, SITU, TDP)

Memiliki feasibility study

\section{METODE PENELITIAN}

\section{Jenis Penelitian}

Penelitian ini menggunakan jenis penelitian deskriptif. Metode penelitian deskriptif adalah suatu metode dalam meneliti status kelompok manusia, suatu objek, suatu kondisi, suatu sistem pemikiran, ataupun suatu peristiwa pada masa sekarang.

\subsection{Lokasi Penelitian}

Lokasi penelitian ini adalah PT Bank Pembangunan Daerah Jawa Barat dan Banten, Tbk Cabang Banjarmasin beralamat di Jalan A.Yani Km 3,5 RT 2 Kel. Kebun Bunga Kec. Banjarmasin Timur Kota Banjarmasin tepatnya di depan Gedung RRI Banjarmasin.

\section{Sumber Data}

Sumber data penelitian ini meliputi data primer dan data sekunder.

1. Data Primer

Dalam penelitian ini data primer diperoleh secara langsung dari sumbernya terutama bersumber dari hasil wawancara dengan staff karyawan bersangkutan pada PT Bank Pembangunan Daerah Jawa Barat dan Banten, Tbk Cabang Banjarmasin.

\section{Data Sekunder}

Data sekunder dalam penelitian ini berupa dokumen, jurnal-jurnal, buku tentang strategi personal selling dan dokumen pada tahun sebelumnya terutama berkenaan dengan sejarah perusahaan, struktur organisasi, dan uraian tugas pada PT Bank Pembangunan 
Daerah Jawa Barat dan Banten, Tbk Cabang Banjarmasin.

\section{Variabel Penelitian}

Variabel yang digunakan dalam penelitian ini adalah :

1. Varibel Bebas

Variabel bebas dalam penelitian ini adalah strategi promosi personal selling.

2. Variabel Terikat

Variabel terikat pada penelitian ini adalah jumlah target produk Kredit Komersial. Kredit Komersial merupakan kredit oleh yang nasabahnya (perorangan atau badan usaha) dipergunakan untuk memperlancar kegiatan nasabah yang bidang usahanya adalah perdagangan (ditujukan untuk membiayai kebutuhan dunia usaha).

\section{Teknik Pengumpulan Data}

Teknik pengumpulan data yang dilakukan dalam penelitian ini adalah:

1. Observasi

2. Wawancara

\section{Teknik Analisis Data}

Teknik analisis data dalam penelitian ini adalah analisis data kualitatif. yakni bahwa aktivitas dalam analisis data kualitatif hanya mendeskripsikan tanpa melakukan perhitungan. Dalam hal ini peneliti mendeskripsikan, menganalisis, dengan cara membandingkan dengan teori tentang strategi promosi personal selling pada PT Bank Pembangunan Daerah Jawa Barat dan Banten, Tbk Cabang Banjarmasin.

\section{HASIL DAN PEMBAHASAN}

Pelaksanaan Strategi Promosi Personal Selling yang dilakukan PT Bank Pembangunan Daerah Jawa Barat dan Banten, Tbk Cabang Banjarmasin

Dari hasil wawancara yang dilakukan peneliti pada staff Pegawai AO (Account
Officer) Komersial PT Bank Pembangunan Daerah Jawa Barat dan Banten, Tbk Cabang Banjarmasin dalam menjalankan strategi bisnisnya khususnya personal selling yang telah dilakukan yaitu dalam hal ini untuk mengembangkan produk Kredit Komersial khususnya di bank bjb itu sendiri ada istilahnya mapping (pemetaan) kredit. Jadi setiap tenaga pemasar dalam hal ini AO (Account Officer) Komersial melakukan dalam pemetaan tersebut dengan cara yang dilakukan adalah Dengan referral (rujukan) artinya AO (Account Officer) Komersial diberi rujukan untuk mengetahui potensi bisnis calon nasabah melalui hasil referensi dari unit kerja lain maupun debitur eksisting. Kemudian melakukan serbu pasar/Teritorial Management artinya promosi personal selling yang dilakukan dengan menawarkan atau memperkenalkan langsung produk Kredit Komersial kepada calon nasabah dengan mengikuti kegiatan nasional atau lokal seperti ajang pameran didaerah setempat. Dan juga Internal Data Mining yaitu personal selling yang dilakukan hanya kepada relasi/nasabah yang sudah ada dengan melakukan penggalian internal pada data base seperti data nasabah tabungan, giro, deposito, precious atau debitur yang sudah lunas.

\section{Masalah yang dihadapi}

Dari hasil wawancara dan observasi yang dilakukan peneliti PT Bank Pembangunan Daerah Jawa Barat dan Banten, Tbk Cabang Banjarmasin memiliki beberapa kendala yang dihadapi yaitu kesulitan di jaringan bisnis dan nasabah yang berpotensial dalam sasaran penyaluran produk Kredit Komersial serta kurangnya informasi data potensial nasabah. Kemudian personal selling yang dilakukan selama ini belum dapat berkembang dengan baik dan pelaksanaan promosi masih kurang maksimal dalam memasarkan produk Kredit Komersial, 
sehingga menimbulkan jumlah pencapaian dan target tidak sesuai yang diinginkan dalam kurun waktu lima tahun terakhir yaitu dari tahun 2013 sampai dengan tahun 2017 yang mengalami target tidak seluruhnya tercapai yang ditetapkan perusahaan.

\section{Bukti Masalah}

Dari hasil observasi yang dilakukan peneliti bahwa PT Bank Pembangunan Daerah Jawa Barat dan Banten, Tbk Cabang Banjarmasin dalam kurun waktu lima tahun terakhir target tidak seluruhnya tercapai pada produk kredit komersial yang ditetapkan perusahaan dan menghasilkan jumlah pencapaian dan target sebagai berikut:

\section{Tabel 4.5 Data Pencapaian dan Target Produk Kredit Komersial}

\begin{tabular}{|c|c|c|c|c|}
\hline No & Tahun & Target & Realisasi & Persentase \\
\hline 1 & 2013 & $1 \mathrm{M}$ & $1.7 \mathrm{M}$ & $174 \%$ \\
\hline 2 & 2014 & $4.5 \mathrm{M}$ & $517 \mathrm{JT}$ & $11 \%$ \\
\hline 3 & 2015 & $3.5 \mathrm{M}$ & $1.1 \mathrm{M}$ & $31 \%$ \\
\hline 4 & 2016 & $38.46 \mathrm{M}$ & $6.99 \mathrm{M}$ & $18 \%$ \\
\hline 5 & 2017 & $59.88 \mathrm{M}$ & $42.50 \mathrm{M}$ & $71 \%$ \\
\hline
\end{tabular}

Sumber: PT. Bank Pembangunan Daerah Jawa Barat dan Banten, Tbk Cabang Banjarmasin

Dapat dikemukakan dari data diatas adalah pencapaian dan target produk Kredit Komersial pada PT Bank Pembangunan Daerah Jawa Barat dan Banten, Tbk Cabang Banjarmasin bahwa dalam kurun waktu lima tahun terakhir mengalami target tidak seluruhnya tercapai bisa dilihat tahun 2013 sudah mencapai target yaitu dengan target 1 $\mathrm{M}$ direalisasikan $1.7 \mathrm{M}$, namun pada tahun 2014 mengalami penurunan yang signifikan yaitu target yang ingin dicapai adalah $4.5 \mathrm{M}$ namun yang direalisasikan hanya $517 \mathrm{jt}$, pada tahun 2015 target yang ingin dicapai adalah $3.5 \mathrm{M}$ namun yang direalisasikan hanya 1.1 M, kemudian pada tahun 2016 yaitu target yang ingin dicapai adalah 38.46 $\mathrm{M}$ namun yang direalisasikan hanya $6.99 \mathrm{M}$ dan pada tahun 2017 target yang ingin dicapai mengalami kenaikan dari tahun sebelumnya yaitu dengan target $59.88 \mathrm{M}$ yang direalisasikan hanya $42.50 \mathrm{M}$. walaupun pada beberapa tahun sudah mengalami kenaikan dari tahun sebelumnya namun target tersebut belum memenuhi target yang ditetapkan perusahaan.

\section{Sebab Terjadinya Masalah}

Dari hasil wawancara yang dilakukan peneliti dengan staff pegawai AO (Account Officer) Komersial pada PT Bank Pembangunan Daerah Jawa Barat dan Banten, Tbk Cabang Banjarmasin sebab tidak tercapainya target karena ada beberapa hal yaitu tenaga pemasar dalam hal ini yaitu AO (Account Officer) Komersial kesulitan di jaringan bisnis dan nasabah yang berpotensial dalam sasaran penyaluran produk Kredit Komersial serta kurangnya informasi data potensial nasabah. Kemudian personal selling yang dilakukan belum dapat berkembang dengan baik dan pelaksanaannya yang kurang maksimal dalam memasarkan produk Kredit Komersial, itu dikarenakan produk Kredit Komersial bukan termasuk produk penjualan utama bagi bank sehingga tenaga personal selling dalam mencapai target dari produk Kredit Komersial belum seluruhnya tecapai, hal ini juga membuat sebagian nasabah kurang mengetahui adanya produk Kredit Komersial tersebut. Serta personal selling yang dilakukan juga hanya kepada relasi/nasabah yang sudah ada atau nasabah sebelumnya saja padahal personal selling disini berperan penting terhadap promosi suatu perusahaan dan berpotensi untuk menemukan calon nasabah baru yang dianggap berpotensial dalam sasaran penyaluran produk Kredit Komersial.

\section{Akibat Masalah}

Permasalahan yang ada pada PT Bank Pembangunan Daerah Jawa Barat dan Banten, Tbk Cabang Banjarmasin saat ini apabila tidak ditangani dengan baik akan 
berpengaruh pada bank itu sendiri, akibat yang timbul dari permasalahan tersebut adalah jumlah pencapaian dan target data yang didapat pada PT Bank Pembangunan Daerah Jawa Barat dan Banten, Tbk Cabang Banjarmasin selama lima tahun terakhir tidak seluruhnya tercapai yaitu tahun 2013 sampai dengan 2017, dikarenakan strategi personal selling yang belum dapat berkembang dengan baik dan pelaksanaan promosi yang kurang maksimal dalam memasarkan produk Kredit Komersial. Hal ini mengakibatkan produk Kredit Komersial yang ada di PT Bank Pembangunan Daerah Jawa Barat dan Banten, Tbk Cabang Banjarmasin kurang diketahui sebagian nasabah. Serta juga mengakibatkan keuntungan untuk bank tidak maksimal dan tidak sesuai dengan yang diharapkan.

\section{Pemecahan Masalah}

Berdasarkan permasalahan yang dihadapi oleh PT Bank Pembangunan Daerah Jawa Barat dan Banten, Tbk Cabang Banjarmasin yaitu target produk kredit komersial yang belum seluruh tercapai. Padahal PT Bank Pembangunan Daerah Jawa Barat dan Banten, Tbk Cabang Banjarmasin mempunyai target yang harus dicapai. Target yaitu sasaran (batas Ketentuan dan sebagainya) yang telah ditetapkan untuk dicapai. Target adalah mengevaluasi daya tarik masing-masing segmen dengan menggunakan variable-variable yang bisa menguantifikasi (menjumlahkan) kemungkinan permintaan dari setiap segmen, biaya melayani setiap segmen, biaya memproduksi produk dan jasa yang diinginkan pelanggan, dan kesesuaian antara kompetensi inti perusahaan dan peluang pasar.

Berdasarkan strategi personal selling yang sudah dilakukan agar berjalan dengan lebih maksimal perlu adanya strategi personal selling yang tepat dalam menggunakan metode. Strategi personal selling yang harus dijalankan agar promosi personal selling berjalan dengan maksimal yaitu:

1. Mencari calon nasabah baru (prospecting)

PT Bank Pembangunan Daerah Jawa Barat dan Banten, Tbk Cabang Banjarmasin melakukan personal selling dengan lebih giat lagi untuk mencari pelanggan bisnis baru yang kemudian dijadikan sebagai pelanggan bisnis potensial bagi perusahaannnya.

2. Komunikasi (communicating)

PT Bank Pembangunan Daerah Jawa Barat dan Banten, Tbk Cabang Banjarmasin melakukan personal selling untuk memberikan informasi yang dibutuhkan oleh pelanggan bisnis tentang produk Kredit Komersial secara jelas dan tepat.

3. Penjualan (selling)

PT Bank Pembangunan Daerah Jawa Barat dan Banten, Tbk Cabang Banjarmasin melakukan personal selling yang dimana harus tahu bagaimana seni menjual, mendekati pelanggan bisnis sasaran, mempresentasikan produk, menjawab keberatan-keberatan serta menutup penjualan.

4. Mengumpulkan Informasi (information gathering)

PT Bank Pembangunan Daerah Jawa Barat dan Banten, Tbk Cabang Banjarmasin melakukan personal selling untuk melakukan riset pasar sehingga mendapatkan informasi tentang pelanggan bisnis dan keadaan pasar serta juga membuat laporan kunjungan baik yang akan dilakukan maupun yang telah dilakukan.

5. Pelayanan (servicing)

PT Bank Pembangunan Daerah Jawa Barat dan Banten, Tbk Cabang Banjarmasin melakukan personal selling untuk memberikan pelayanan kepada pelanggan bisnis, mengkomunikasikan masalah pelanggan bisnis, memberikan bantuan teknis dan melakukan pengiriman. 


\section{Pengalokasian (allocation)}

PT Bank Pembangunan Daerah Jawa Barat dan Banten, Tbk Cabang Banjarmasin melakukan personal selling untuk memutuskan pelanggan bisnis mana yang akan lebih dulu memperoleh produk bila terjadi kekurangan produk pada produsen.

Selanjutnya langkah-langkah strategi personal selling yang harus dilakukan oleh tenaga personal selling PT Bank Pembangunan Daerah Jawa Barat dan Banten, Tbk Cabang Banjarmasin yaitu:

1. Mencari calon nasabah (prospek) dan mengkualifikasinya

Langkah pertama dalam penjualan adalah mengidentifikasi calon nasabah dan mengkualifikasinya. Semakin banyak perusahaan yang bertanggung jawab untuk mencari calon nasabah dan mengkualifikasikan petunjuk sehingga tenaga personal selling dapat menggunakan waktu mereka yang tidak banyak untuk melakukan apa yang dapat mereka lakukan dengan baik. Kemudian tenaga personal selling dalam mengkualifikasinya dengan menghubungi calon nasabah lewat telepon ataupun surat untuk menilai tingkat minat dan kapasitas uang mereka.

\section{Prapendekatan}

Tenaga personal selling harus belajar sebanyak mungkin bagaimana calon nasabahnya. Tenaga personal selling juga harus menetapkan tujuan kunjungan, kemudian mengkualifikasi calon nasabah, serta mengumpulkan informasi dan melakukan penjualan segera. Adapun tugas lainnya adalah memilih pendekatan kontak terbaik seperti menghubungi nasabah lewat telepon atau surat, melakukan kunjungan pribadi kepada nasabah secara langsung. Pada akhirnya, tenaga personal selling harus merencanakan keseluruhan strategi penjualan untuk calon nasabah.

\section{Presentasi dan demonstrasi}

Tenaga personal selling menyampaikan "kisah" produk Kredit Komersial kepada pembeli menggunakan pendekatan fitur, keunggulan (advantage), manfaat (benefit), dan nilai (value) (FABV). Fitur disini menggambarkan karakteristik fisik penawaran pasar seperti fitur produk tersebut yang menjelaskan mengapa fitur itu memberikan keuntungan kepada calon nasabah. Kemudian manfaat menggambarkan seperti manfaat ekonomi, teknis layanan dan sosial yang dihantarkan oleh penawaran. Dan nilai menggambarkan nilai penawaran produk. Namun sering kali tenaga personal selling menghabiskan terlalu banyak waktu dalam menjelaskan fitur produk sehingga sering kali tidak cukup waktu untuk menekankan sisi lainnya seperti manfaat dan nilai produk yang ditawarkan.

\section{Mengatasi keberatan}

Calon nasabah biasanya mengajukan keberatan. Yang menimbulkan Resistensi psikologis meliputi resistensi terhadap interferensi, preferensi terhadap merek/produk yang sekarang digunakan, apatis, tidak bersedia melupakan sesuatu. Hubungan yang tidak menyenangkan sering diciptakan oleh tenaga personal selling sendiri. Oleh karena itu untuk menangani keberatan ini tenaga personal selling harus mempertahankan pendekatan positif seperti meminta calon nasabah menglarifikasi keberatan, mengajukan pertanyaan dengan cara di mana calon nasabah menjawab keberatannya sendiri, menyangkal keakuratan hal yang menjadi keberatan tersebut atau mengubah menjadi alasan untuk membeli.

\section{Penutupan}

Tanda penutupan dari calon nasabah meliputi tindakan fisik, pernyataan atau komentar dan pertanyaan. Tenaga personal selling dapat menanyakan pesan, merekapitulasi poin-poin yang disepakati, menawarkan untuk membantu menulis pesanan, bertanya apakah menginginkan produk $\mathrm{A}$ atau produk $\mathrm{B}$ atau menunjukan kerugian apa yang dapat dialami calon nasabah jika tidak melakukan pembelian sekarang. Tenaga personal selling juga dapat menawarkan insentif khusus untuk menutup 
seperti harga khusus, kuantitas ekstra, atau cinderamata.

6. Tindak lanjut dan pemeliharaan

Tindak lanjut dan pemeliharaan diperlukan untuk memastikan kepuasan nasabah dan terluangnya kerja sama. Segera setelah menutup penjualan, tenaga personal selling harus menyatukan semua data yang diperlukan tentang waktu pengiriman, syarat pembelian, dan masalah penting bagi nasabah. Tenaga personal seling juga harus menjadwalkan kunjungan tindakan lanjut setelah pembelian untuk memastikan instruksi dan layanan yang tepat serta mendekteksi semua masalah, kemudian memastikan minat tenaga personal selling kepada nasabah dan mengurangi disonansi kognitif. Selanjutnya tenaga personal selling juga harus mengembangkan rencana pemeliharan dan pertumbuhan bagi nasabah.

Dalam melakukan strategi personal selling juga ada beberapa prinsip-prinsip yang bisa dilakukan dalam mencapai target yaitu:

1. Persiapan yang matang

Persiapan yang matang ini meliputi pengetahuan:

a. Mengenal pasar dimana produk Kredit Komersial akan dijual yaitu meliputi keterangan-keterangan mengenai keadaan perekonomian pada umumnya, persaingan, trend, harga, dan sebagainya.

b. Mengenai nasabah dan calon nasabah. Dalam hal ini perlu diketahui buying motives, yaitu apa motif orang untuk membeli dan buying habits, yaitu kebiasaan orang membeli.

c. Cukup mengetahui tentang produk yang akan dibelinya. Konsumen sangat tidak senang pada penjual yang tidak dapat menjawab pertanyaan-pertanyaan konsumen dan sebagaimana biasanya konsumen ingin mendapatkan berbagai macam informasi mengenai barang yang akan dibelinya.

d. Prinsip dasar harus diketahui oleh penjual karena dengan demikian penjual dapat mempengaruhi konsumen untuk membuat transaksi yang menguntungkan kedua belah pihak.

2. Mendapatkan atau menentukan tempat pembeli

Untuk mendapatkan pembeli/konsumen, seorang tenaga personal selling harus berpedoman kepada kebijaksanaan perusahaan mengenai chanell of distribution yang dipergunakan.

\section{Merealisasikan penjualan}

Meskipun dimana terjadinya penjualan tersebut beraneka ragam, tetapi langkahlangkah yang diambil yang diambil oleh tenaga personal selling dalam proses penjualan adalah:

a. Pendekatan dan pemberian hormat

b. Penentuan kebutuhan pelanggan

c. Menyajikan barang yang efektif

d. Mengatasi keberatan-keberatan

e. Melaksanakan penjualan-penjualan

4. Menimbulkan goodwill setelah penjualan terjadi

Jika penjualan terjadi dengan baik, maka pembeli akan memperoleh barang sesuai dengan yang diinginkan, dan penjual memperoleh laba. Hal ini akan mempunyai pengaruh baik terhadap pembeli tersebut, yaitu akan membeli lagi kepada penjual yang sama dikemudian hari.

\section{KESIMPULAN DAN SARAN}

Pelaksanaan strategi personal selling yang selama ini dilakukan PT Bank Pembangunan ada beberapa cara. Di bank bjb sendiri itu ada istilah nya mapping (pemetaan) kredit cara yang dilakukan adalah Dengan referral (rujukan), Kemudian melakukan serbu pasar/Teritorial Management Dan juga Internal Data Mining. Namun dalam pelaksanaan personal selling yang dilakukan masih belum dapat berkembang dengan baik dan pelaksanaannya yang kurang maksimal dan kurang tepat hal ini juga membuat sebagian nasabah kurang mengetahui produk Kredit Komersial dan juga mengalami target produk 
Kredit Komersial yang belum seluruhnya tercapai. Dalam pelaksanaan personal selling yang masih belum dapat berkembang dengan baik serta pelaksanaannya yang kurang maksimal dan tepat sehingga diperlukan adanya strategi yang tepat agar promosi personal selling berjalan dengan lebih maksimal. Strategi personal selling yang bisa dijalankan seperti: mencari calon nasabah baru (prospecting), komunikasi (communikating), penjualan (selling), mengumpulkan informasi (gathering), pelayanan (servising), pengalokasian (allocation). Selanjutnya langkah-langkah strategi personal selling yang bisa dilakukan tenaga personal selling seperti: Mencari calon nasabah dan mengkualifikasinya, Prapendekatan, Presentasi dan Demonstrasi, Mengatasi keberatan, Penutupan, Tindak lanjut dan pemeliharaan.

\section{DAFTAR PUSTAKA}

Adha, Dini Kusdewantari. 2016. "Strategi Personal Selling Guna Meningkatkan Jumlah Nasabah Tabungan $\mathrm{Ku}$ pada PT Bank Rakyat Indonesia (Persero) Unit Ahmad Yani Banjarmasin”.

Ali, Hasan. 2013. Marketing dan Kasuskasus Pilihan. Yogyakarta : CAPS (Center For Academic Publishing Service).

Alma, Buchari. 2007. Manajemen Pemasaran dan Pemasaran Jasa. Bandung : Alfabeta.

Astuti, Nadia Suci Dwi. 2017. "Pengaruh Positioning Melalui Proses Personal Selling Terhadap Keputusan Pembelian Konsumen Pada Produk Ekamant Di Bandung."

Cannon, Perreault dan Mc Carty. 2008. Manajemen Pemasaran Dasar. Jakarta : Salemba Empat.
Hidayah, Nurul. 2016. "Strategi Personal Selling Untuk Meningkatkan Jumlah Nasabah Simpanan Pada PT Bank Kesejahteraan Ekonomi Kantor Cabang Banjarmasin".

Kotler, Philip dan Kevin Lane Keller. 2012. Manajemen Pemasaran. Edisi 12. Jakarta : Erlangga

Kotler, Philip and Gary Armstrong. 2012. Prinsip-prinsip Pemasaran. Edisi 12. Jilid 1. Jakarta : Erlangga.

Pratiwi, Aldilla Gita. 2016. "Peranan Personal Selling Guna Meningkakan Produk JS Siharta pada PT Asuransi Jiwasraya (Persero) Cabang Surakarta".

Rachmawati, Mega. 2015. "Pengaruh Citra Merek Dan Bauran Promosi Terhadap Minat Nasabah Membeli Bancassuranse Bringin Life Di PT Bank Rakyat Indonesia (Persero) Tbk Cabang Asia Afrika Bandung".

Tjiptono, Fandy. 2008. Manajemen Pemasaran. Yogyakarta : Andi.

Sumber lain :

Aini,Nur.2014.http://www.academia.edu/196 44408/IMPLEMENTASI_GAYA_BAH ASA_DALAM_PERSONAL_SELLIN $\mathrm{G}$

Belmy,2016.http://belmy.info/pengertianpencapaian-target-menurut-ahli.html

Rahman,Ainur.2016.https://peduli99.blogspo t.com/2016/03/pengertian-manajemenpenjualan.html

Getedu,2017.https://marketingeducate.blogsp ot.com/2017/10/definisi-strategimenurut-para-ahli.html

Sanjaya,Ade.2015.http://www.landasanteori. com/2015/07/pengertian-kreditmenurut-definisi para.html

http://www.bankbjb.co.id/id/corporatewebsite/produk-dan-layanan.html 